\title{
Dose Calculation Error in Application Program
}

National Cancer Institute

\section{Source}

National Cancer Institute. Dose Calculation Error in Application Program. NCI Thesaurus.

Code C63220.

Problem associated with the written program code or application software used by a device to calculate specific measurements or quantities managed by the device. 